\title{
Study on Government Information Disclosure of Government Website
}

\section{Platform}

\author{
Cuihua Liu ${ }^{1}$ \\ ${ }^{1}$ School of Education Science, Shangqiu Normal University, Shangqiu, Henan 476000 \\ 346591653@163.com
}

KEYWORDS: Government Information Disclosure; Website Platform; Problem; Countermeasure

\begin{abstract}
: according to the government information disclosure of government departments, we start from the Henan provincial government departments website, through the analysis of its website domain name, website click rate and other technical indicators, the provincial government departments in the use of its Web site open government information problems, and put forward countermeasures to improve the public service level of government departments.
\end{abstract}

\section{Introduction}

How to use government websites do better disclosure of government information, has become the focus of attention of government leaders, experts and scholars problems to be solved. At present, domestic and foreign government information disclosure about the study of e-government, government portal are many, but the combination of government websites FOI still rare. Focus on the combination of the two, we start on.

\section{Government Websites and FOI Overview}

With the development of e-government and governments at all levels continue to improve, government departments website has become the focus of e-government construction deepening. Government websites by the various functional departments of the government established by the portal, is a realization of the integration of resources, internal and external communication, while the business sector to expand the Internet application platform; the government for the public sector, businesses and relevant government on the lower level functional departments to provide electronic services window, so that they can from this simple, quick to find personalized information portal, access to personalized information services and carry out administrative activities; management, query, daily business operations and office network platform collaboration .

"Open Government Information" refers to all levels of government and its subordinate departments, organizations, according to the standard, program and time limits established by the government or the unit to handle matters of social affairs activities, the use of carrier media made public, permit the user to query, Download, extract, listen to, watch, etc., according to the use of available information, to accept citizens, legal persons or other organizations involved in democratic supervision, a system management.

Government Information Disclosure" and "government website" as a keyword search on Clin knowledge service platform, finishing the period 2001-2014 drawn their respective research trends, as follows: 


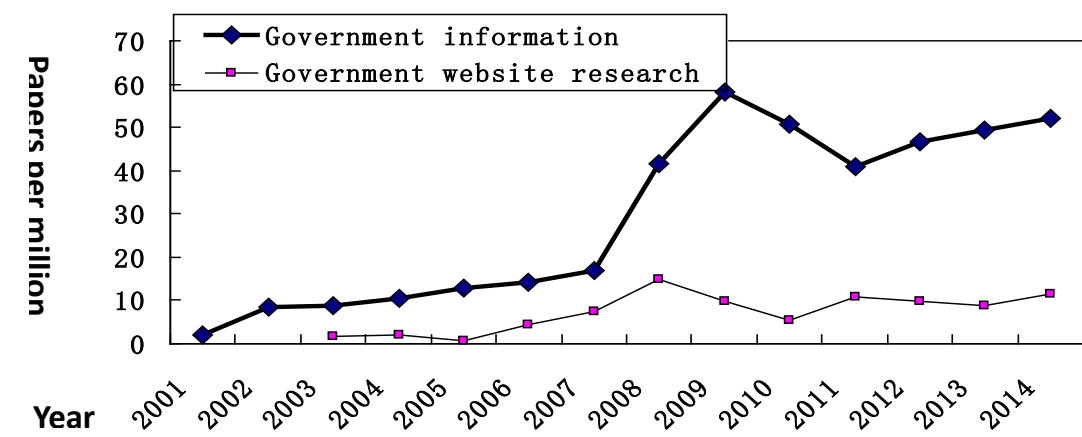

Fig. 1 Articles database FOI research and academic research trends government websites

Figure 1 shows the "Open Government Information," the study, 2001-2014 upward trend, related research since 2007 has grown rapidly. Research generally government website also on the rise. It is worth noting that 2008, 2009 and the government is open government information website research climax, showing consistency.

Henan Province in various government departments, based on government websites and government information disclosed binding, we analyzed and discussed from the constraints and strategies to be taken.

Second, the government information department of the government website platform disclosed Problems

Investigation against government websites, we Henan government departments site, for example, with the domain, the associated IP network CTR amount (1), backlinks (2), PV amount (3) variable using Chinese ALEXA software on-line inquiry three government departments Henan variable data site, sorted out in table 1, as follows:

Table 1, the Henan provincial government departments in this domain and website hits Statistics (Note: * indicates that the associated data are not statistics)

\begin{tabular}{|l|l|l|l|l|}
\hline Name of Department & Website & $\begin{array}{l}\text { IP } \\
\text { Num }\end{array}$ & $\begin{array}{l}\text { Backlink } \\
\text { s }\end{array}$ & PV Num \\
\hline $\begin{array}{l}\text { Provincial Bureau of } \\
\text { Statistics }\end{array}$ & http://www.ha.stats.gov.cn & 26400 & 3068 & 158400 \\
\hline $\begin{array}{l}\text { Provincial Department of } \\
\text { Education }\end{array}$ & http://www.haedu.gov.cn & 17400 & 617 & 62640 \\
\hline $\begin{array}{l}\text { Provincial Human } \\
\text { Resources and Social } \\
\text { Security Department }\end{array}$ & http://www.ha.hrss.gov.cn & 8400 & 1053 & 42000 \\
\hline Provincial Tourism Bureau & http://www.hnta.cn & 7200 & 300 & 23020 \\
\hline $\begin{array}{l}\text { The provincial government } \\
\text { office }\end{array}$ & http://www.henan.gov.cn/ & 3600 & 1243 & 14400 \\
\hline $\begin{array}{l}\text { Auditing http://www.shenji.henan.gov. } \\
\text { cn }\end{array}$ & 3600 & 1243 & 14400 \\
\hline $\begin{array}{l}\text { Provincial Housing and } \\
\text { Urban http://www.hnjs.gov.cn } \\
\text { Department Construction }\end{array}$ & 2800 & 568 & 12300 \\
\hline $\begin{array}{l}\text { Provincial Department of } \\
\text { Culture }\end{array}$ & http://www.hawh.cn & 2709 & 623 & 11000 \\
\hline $\begin{array}{l}\text { Provincial Department of } \\
\text { Agriculture http://www.haagri.gov.cn }\end{array}$ & 1967 & 563 & 17600 \\
\hline
\end{tabular}




\begin{tabular}{|l|l|l|l|l|}
\hline $\begin{array}{l}\text { Department of Water } \\
\text { Resources }\end{array}$ & http://www.hnsl.gov.cn & 2340 & 242 & 17040 \\
\hline $\begin{array}{l}\text { Provincial Industry and } \\
\text { Information Technology } \\
\text { Department }\end{array}$ & http://www.iitha.gov.cn & 2568 & 149 & 11400 \\
\hline $\begin{array}{l}\text { Provincial Department of } \\
\text { Transportation }\end{array}$ & http://www.hncd.gov.cn & 1760 & 392 & 11000 \\
\hline $\begin{array}{l}\text { Provincial Population and } \\
\text { Family } \\
\text { Commission http://www.hnjsw.gov.cn }\end{array}$ & 1500 & 133 & 10700 \\
\hline $\begin{array}{l}\text { Provincial Public Security } \\
\text { Bureau }\end{array}$ & http://www.henanga.gov.cn & 1600 & 140 & 10020 \\
\hline Provincial Energy Bureau & http://www.hndrc.gov.cn & 1500 & 511 & 9070 \\
\hline $\begin{array}{l}\text { Provincial Development } \\
\text { and Reform Commission }\end{array}$ & http://www.hndrc.gov.cn & 1500 & 511 & 9070 \\
\hline $\begin{array}{l}\text { Provincial Department of } \\
\text { Finance http://www.hncz.gov.cn }\end{array}$ & $*$ & 230 & $*$ \\
\hline Provincial Finance Office & http://henanjr.gov.cn & $*$ & 20 & $*$ \\
\hline
\end{tabular}

Table 1 illustrates the 18 government websites in Henan, look at user awareness of the portal through three variables, there are 10 sector users attention higher, more prominent of the "Provincial Bureau", "provincial education hall "," provincial human resources and Social security "," provincial Tourism Bureau "," provincial government office "," Auditing "," provincial department of culture, "and other departments. IP amount of other government departments, PV due to the amount of data is too low, some data Chinese ALEXA software cannot even provide, such as "Provincial Finance", "provincial finance office." In addition, "provincial Energy Board" and "Provincial Development and Reform Commission," the Web site domain name and website hits agreed to become de facto "government information website platform next two government departments Offices open."

For government websites government information disclosure in Henan research, there are problems.

\section{A. The Legal Environment is not Perfect}

On the one hand, "People's Republic of China Information Disclosure Ordinance" of government information disclosure principles, scope, modalities and procedures regulates; on the other hand, "Secrets Act" and the scope of confidentiality was strictly limited. In the case of public and confidential relationship is not completely straightened out, leading to two undesirable consequences: First, the name of a confidential government information disclosure reluctant to open, be a reason for a number of government departments and officials concealed information should be disclosed further rent-seeking; two is ill-defined public and confidential, secret chaos do not speak openly, resulting in the loss of intangible assets of state-owned sector. In addition, although the provisions of statutory law make the form of open government information, but there is no clear way which can mandatory carrier. In the Government Gazette, government websites, press conferences, press, radio, television and other convenient for the public to know of six ways, in addition to the Official Gazette and is outside the statutory mandatory, other government only 5 ways you choose. The fact is that a lot of government information disclosure of government 
departments did not use other forms other than the form of the Official Gazette. This gives the user access to government information is expected to bring hindered by government websites.

\section{B. Construction of Government Websites Lack Normative}

Construction site of the Henan Provincial Government departments lack of unified normative. First, the domain (see Table 1) name is not uniform. Its domain types are: Pinyin Abbreviation, pinyin spelling, pinyin spelling and abbreviations mixing, mixing pinyin abbreviation and acronym, abbreviation, etc. The problem is that the same type of domain names is different. For example, "Public Security Bureau in Henan Province," the website domain name "http://www.henanga.gov.cn", belonging to the pinyin spelling and abbreviations mixed types, "henanga" meaning "of Henan Public Security", " henan "as" Henan "pinyin spelling of the word," ga "is" "the first letter of the word Pinyin, but the" public security gov" is the English" goverment "word interception style abbreviations. Secondly, the site columns settings are not standardized. The same information and services home are different plates at different government websites in different ways. Again, some government departments Web page design is unreasonable. Outstanding performance in: some government departments Home information disorganized; some government departments Home information too simple, when you click on the title link is empty.

\section{The Government Information Disclosure Content}

First, some government websites disclosure of government information, forms and procedures are not standardized. Government information disclosure with a lot of randomness, but the public is willing to passively accept the government on its public information portal. From the information content of the site, the Henan government websites rarely follow accessibility design concepts and standards, namely non-text information, video, audio, text descriptions or pictures provided for the convenience for the special populations. Second, some government websites classification criteria for the classification of information is not unified. Such as "Download Forms" is a "public service" in the "Henan Province Department of Education" website column, and in the "Henan Provincial Public Security" site is owned by "online services" column. Third, government websites government information navigation to be improved, the reverse link data in Table 1, the Henan provincial government department websites can illustrate this point. In addition, some of the large number of air links and dead links exist on government websites. On its Web site home page you can see almost all of the information to be included in the column, click on the headline as the link, but it is the frequent appearance of a "file not found" prompt.

\section{The Information Update Lag, Lack of Citizen Participation}

Government updates lag, which has almost become the site of some government departments "disease." Some of the information we are all familiar with the site's home page is still living in a prominent position; department heads have been appointed a few months, the site is still led by its predecessor news photos; on the government website or contact telephone number is not answered or is empty, published e-mail address does not exist; especially the bureau and departments set up an overview of the situation, and cannot do the same to update and change the facts, and so on. Second, the lack of citizen participation. Table 1 in the amount of IP Henan government department website, PV amount generally not high, website hits also needs to be improved. Through a lot of investigation and interviews, the Henan Provincial Government departments visit the website, and more inclined to find citizens access to government information from traditional newspapers and television, but the government information public government websites insufficient attention. Government has not yet become public website information disclosed beneficiaries. 


\section{Countermeasures of the Government Website Platform FOI}

\section{A. Further Improve the Legal Environment}

For the emergence of the "Regulations" issue, supporting the development of specific systems approach, the contents of the provisions of the "Regulations" refinement. A list of specific types of non-public information provisions boundaries to avoid "Secrets Act" is unclear, according to government information disclosure has operated, thereby enabling the "Regulations" in principle better implemented. In the "Regulations" FOI has six ways, but only the Government Gazette is the official carrier and mandatory, others are options. The government is the first internet site to fight the FOI, "Government Information Disclosure Law" would make government websites as FOI legal and force vectors.

\section{B. The Construction of Sustainable Development Government Websites}

First, establish a strong leadership. Office of the Government of Henan Province set up a special agency to manage, maintain government information disclosure Henan Provincial Government website. Accordingly, various government departments directly under the office should set up such a body or person responsible for the department to assign work site, while start "command", strengthen the government information department of the public. Secondly, strengthen technical management of government department websites. The department website, website construction and maintenance should be technical personnel. Third, strengthen the management of government information disclosure. Government websites should be different from entertainment, commercial site, page design to meet simple and clear, convenient and practical principles; for a moderate number of page sections; each section of the classification to science; the distribution level to make it clear; the page layout harmonization. Some government departments in their Home placed excessive content, users do not necessarily want to drag the mouse several times to find the information desired content. For example, the federal government portal allows citizens by topic rather than by department more effectively search for information and access to government services. Government websites provide a package of solutions, users just type the topic, you can find the information or access to services.

\section{Strengthen Co-ordination Skills and Ability to Navigate Government Websites}

Simple information retrieval, information disclosure and other basic functions cannot meet the needs of the public, building a strong collaboration and interactivity "one-stop" government websites become a trend. First, the government information resource site's cross-sectoral, cross-regional integration, and improve its information resource database. Government website pages can be linked to the higher level, the same level (provinces), subordinate department website for government information to the public to provide convenient links to provide detailed information for the departments work. Secondly, standardize information disclosure, establish a scientific classification and navigation. For inconsistent visibility, quite different types of open government information, solution is to establish a standard "open government information directory," and improve the quality of government websites disclosure of government information from the system. Establish a scientific classification and navigation, view information not click title should be distinguished from the color of the title, to provide humanistic experience and convenience.

\section{Promote Public Participation and Promote Positive Interaction}

We propose to interactive government department website a few suggestions: 1, establish a "customer first" philosophy to guide public legal and orderly participation. Government Website 
Design Services from section to render service window, and by the ease of the site into the other site, query, ease of searching for information, should reflect the "customer first" philosophy. 2, bridging the digital divide to achieve universal access. Improve the quality of public, universal education computer network, Duocuobingju committed to expanding the scope and use of government information resources population covered. 3, improve the online interaction mechanisms. Focus on building leadership mail channels; enhance online interview information, strengthen online talk show topic planning; expand the scope of radiation the online survey; strengthen BBS forums and message boards building. 4, Implementate building of institution and security interaction effect. Strengthen public participation in the government website construction system, the implementation of various government departments as the responsibility of the main responsibilities interaction, urging government departments to actively participate in interactive sites, to avoid "popular participation, the site will not be accepted" phenomenon. On an interactive process to form a virtuous circle.

\section{REFERENCE:}

[1] Xiong Chengyu. Information Society 4.0 [M]. Changsha: Hunan People's Publishing House, 2002: 7.

[2] Zhao Fang. Accessibility of Government Websites Situation Construction [J]. Nanjing University of Posts and Telecommunications (Social Science Edition), 2012 (1): 20. 